\title{
IMPACT OF OPEN SPACES IN SYNTHESIS OF NEIGHBOURHOOD IN URBAN CONTEXT
}

\author{
Upama Sen ${ }^{1}$ \\ ${ }^{1}$ School of Architecture, GITAM University, Andhra Pradesh, India
}

\begin{abstract}
Cities have always been the center of urbanization. The impact of urbanism must take into account many variables. The urban population is an agglomeration of people with different profession, ethnicity, culture, class, religion, etc. The diversity, if not consolidated to form a rich urban culture, might clash and create intolerance amongst communities. Cities thus must provide neighborhood for people to comfortably overcome their inhabitations and interact with each other to build a sustainable society. Open urban spaces have always fostered social interaction which in turn nurture valuable cultural exchange to build a rich urban heritage. The article aims to understand the character of any open space and its importance in building the urban society.
\end{abstract}

Keywords: - Urbanization, open spaces, social interaction, culture, community

\section{INTRODUCTION}

Cities are more than just magnificent built forms and people. Most livable cities in the world are recognized for their open spaces and culture.[1] Urban Morphology of cities show the gradual decrease and decease of open spaces with the process of urbanization. These open spaces often provide platform for social interactions and cultural exchange in diverse urban communities, and also has environmental, health and socio-economic advantages. Despite of several benefits, urban spaces are victims of rapid urbanization.

\section{WHY CITIES ARE THE POINT OF FOCUS?}

Until the Industrial revolution not more than $10 \%$ of the world's population inhabited in cities. But presently more than half of the global population resides in urban areas. Cities provide better employment opportunities. But apart from that there are several social attractions like better standards of living, education, attraction of the city life, etc. which leads to immigration. The Urban matrix is thus getting denser with time and by 2050 , over $70 \%$ of the world will be urban dwellers. [2].

With population overgrowth cities are continuously facing challenges like housing shortage, acute water crisis, illegal tenantments, increase in crime rate, etc. But in this scenario, one of the major aspects that escapes our vision is the consequence of urbanization on the society.

Rural life is based on Community living and fosters social interaction, nurtures cultural growth. City life lacks these. Urban areas are characterized by huge social and cultural diversities. In busy urban life people have less or no time for social interaction which leads to loneliness, depression and insecurity among citizens. Important issues like the loss of local identity, cultural values and social life is so prevalent that the remark that "cities are places of work and not places to live" is becoming more and more pertinent, especially in big cities.

\section{OPEN SPACES: BENEFITS AND OPPORTUNITIES}

The term public open space in an urban environment encompasses a variety of spaces that are freely accessible to the wider community. They can be any parcel of land or water body in an urban area that is not covered by any built form or any undeveloped land.[3]

Situated within the urban fabric of a city, these open spaces serves as relief spaces and contribute to the quality of life in many ways with direct environmental and health benefits (such as groundwater recharge areas, cleansing of air, and separation from hazards). They serve as an arena for different social activities, culture and value exchange, citizenship, etc. and build up a neighborhood. They provide a platform for social interaction \& fosters community development, serves for any recreational or leisure requisite of a community. They are key ingredients in the cities' sustainability. Natural features and spaces are important in defining the distinctive character of each place. With its architectural and aesthetic elements, they form an essential part of the urban heritage.

\section{NEIGHBOURHOOD AND SOCIAL WELL- BEING}

Outdoor Interaction spaces are of a wide variety but each holds a huge potential in moulding the urban community by making grounds for people to meet, interact, and share. The Urban population is mostly cosmopolitan in nature. Thus interacting platforms are hugely necessary for mingling of the cultures for all to stay in peace and harmony.

“Open space has also been described from a user's point of view as being an arena that allows for different types of activities encompassing necessary, optional and social activities" Gehl, 1987. 


\subsection{Civic Squares and Parks}

Central squares serves as interaction place for people in many parts of the world. They hold a node for different activities throughout the duration of the day. In places around the globe it has been seen that families go for evening stroll around squares, have evening snacks and return. Throughout the day elderly people mostly are found there while in the morning joggers are frequent.

\subsection{Streets}

Similarly city streets invite people from all walks of life to meet, talk, spend time together, exchange cultures, etc. Yet in most cities, streets are a vastly undervalued public asset. Streets with promenade, wide sidewalks, shopping arena, food joints, interesting streetscapes and landscape features engage people in different ways. The places turn into outdoor living rooms, where it's fun to just linger around, walk, engage in a conversation and mingle with the crowds. Many cities like Copenhagen have streets that are closed to vehicular traffic, partially or throughout the day. It creates a platform for people to rub shoulders with others from the community, stop for a conversation without the noise or distractions of traffic. They often harbour street performances, exhibitions, and other features that encourage interaction. The flow of pedestrians enhance the business of shops on those streets. The Champs Elysees in Paris with palaces and gardens at one end, the Arc de Triumphed at the other, and wide sidewalks lined with trees with intriguing shops and cafes, invites people from all walks of life to spend time there.

Eating and drinking together fosters community-building. The presence of cafes, restaurants and bars thus may be a major factor in creating good socio-urban spaces.

\subsection{Market Places}

Market represents important public spaces. They were probably the original place for human interaction even before cities existed. The Agora of Athens, being a prime example of marketplace and civic center was the most significant part of the ancient city. Apart from being a place for trade and commerce, it was also a place where people engaged in discussions on varied topics like business, politics, current events, etc. The Agora wonderfully portrays different aspects of life of the people of one of the great ancient cities. [3] Market have always played a potential role in growth of various civilizations. They act as a focal point for a locality and as a hub of connection. They engross people in different ways apart from just buying and selling and a lot of livelihoods develop around them. People of different age groups, professions, ethnicities, cultures, class and creed are often seen there together.

Chandni Chowk, one of the oldest markets in Delhi is an appropriate example of amalgamation of various faiths, values, spiritual and religious setups and has been functioning harmoniously ever since. [4]

\subsection{Around the Building}

Spaces around iconic buildings also serve as the sites for various gatherings. It often harbours local performances, rallies, speeches, ceremonies, events that gathers crowd and allows people to interact with each other. Martin Luther King, Jr. delivered his iconic "I Have a Dream" speech which led to the Civil Rights movement, from the steps of the Lincoln Memorial in Washington, DC.

\subsection{Ghats/ Waterfronts}

Ghats are embankments along any water-body. Historical evidences show that civilizations always flourished well along river banks, thus ghats have always been major places of importance.

Varanasi in India is known worldwide for its many ghats along the river Ganges, where pilgrims perform ritual ablutions. They have always been a popular visitors' attraction. They create a platform that holds different activities like performing rituals, offerings, holy bath, informal promenade, artists' arena for performing arts (arti), burning ghats for travelers to heaven, etc.

The Sabarmati Riverfront development in Ahmedabad, India has succeeded in restoring the city's relationship with its river.[5]

Waterbodies often have immense cultural value. They can be similarly developed into places of interest which would not only add to aesthetics but also create a meaningful character of the place.

\subsection{Fairs and Festivals}

Fairs, carnivals, exhibitions attract masses. Down the ages these used to be opportunities of trade and commerce, social and cultural exchange between communities. Fairs may be of different types- religious, cultural, commercial, etc. Each provides people with ample activities to indulge in. The Kumbh Mela in India is a massive Hindu pilgrimage which is one of the largest peaceful gathering in the world.

Festival are celebrations of joy. They accounts for huge social interaction and provide the grounds for mingling of the different cultures. People, irrespective of their social status, observe these festivals with friends and families with great enthusiasm. It brings about a sense of unity and togetherness amongst people keeping aside their differences.

\subsection{Beneath a Tree}

Underneath of trees have served as interaction spaces since ages. This is a very common image in old Indian cities like Varanasi. Friends sit there in groups and enjoy themselves. Even strangers turn friends chatting beneath trees. These kind of elements bring about a strong sense of belonging community feeling and develops the neighborhood of a place. 
Often small temples come up beneath significant trees like banyan or peepal which are considered to be sacred according to Hindu Religion. Gatherings occur on auspicious days which lead to social interaction, and cultural exchange.

\subsection{Tea stall (chai joint)}

Tea stalls are major social interactive spaces in many Indian cities. These are the places where people from various walks of life stop for refreshment and indulge into intellectual exchange of a vivid range of topics varying from sports to politics.

Men after a day's hardship or during certain parts of the day often gather at tea stalls and engage in various talks. This is an age old scenario in many Indian towns. This is not merely an act of conversation but also acts as stress busters, a relaxing activity for the mind and enhances communication among people.

\section{CONCLUSION}

Urban open spaces are often undervalued as precious public assets as they cannot be valuated just in monetary terms. Its valuation is difficult to calculate from an economic point of view because of its nil market price. Despite of their benefits, these areas are affected by rapid urbanization. Importance of designing of open urban spaces along with new development or conservation of existing ones must be realized for building more livable cities. In this way issues like culture and identity crisis, loneliness, physical and mental health conditions in citizens, etc may be addressed.

\section{REFERENCES}

[1] Article on Urban planning and the importance of green space in cities to human and environmental health from Healthy Parks Healthy People Central: : http://www.hphpcentral.com

[2] UN report: World's biggest cities merging into 'megaregions', 2010

[3] The Agora, The Ancient City of Athens from http://www.stoa.org

[4] Chandni Chowk - The Unkempt Paradise from https://www.vijaygoel.in

[5] "Sabarmati Riverfront Development"

\section{BIOGRAPHY}

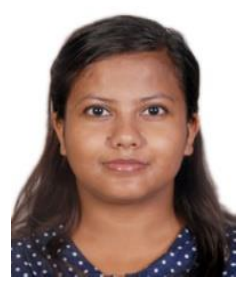

Upama Sen: She completed her architecture degree from School of Architecture, GITAM University in 2017. She is passionate about urban design and sociology and is deeply interested in designing socially and culturally meaningful spaces. 